\title{
殺菌剂イプコナゾールおよびメトコナゾールの開発
}

熊 沢 智, 伊藤 篤 史, 最勝寺俊英 ${ }^{\dagger}$, 中 馬 寛 ${ }^{\dagger}$

尅羽化学工業株式会社錦総合研究所

†吳羽化学工業株式会社合樹・化学品事業部化学品開発部

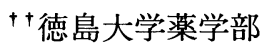

\section{Development of New Fungicides, Ipconazole and Metconazole}

\author{
Satoru Kumazawa, Atsushi Ito, Toshihide SaIshouI ${ }^{\dagger}$ and Hiroshi Chuman ${ }^{\dagger \dagger}$ \\ Nishiki Research Laboratory, Kureha Chemical Industry Company, Ltd., \\ 16 Ochiai, Nishiki-machi, Iwaki, Fukushima 974-8686, Japan \\ ${ }^{\dagger}$ Chemicals and Agrochemicals Development Department, \\ Kureha Chemical Industry Company, Ltd., 1-9-11, Nihonbashi Horidome-cho, \\ Chuo-ku, Tokyo 103-8522, Japan \\ ${ }^{\dagger \dagger}$ Faculty of Pharmaceutical Sciences, The University of Tokushima, \\ 1-78 Shomachi, Tokushima 770-8505, Japan
}

\section{は じめに}

世界人口の急激な増加が予想される状況下で, 食糧確保 の為の農業の生産性向上は従来にも増して重要な問題と なってきている，農業生産における農薬の重要性はここで 述べるまでもなく，農薬は全世界で広範囲に利用されてい る．その一方で，1) 環境への影響を軽減させるための低薬 量化, 低毒性化への要求, 2) 薬滖耐性菌の進展, などによ ク,さらに理想的な薬剤の創製が望まれている.

1980 年代前半には, 当時最も研究の盛んであったアゾー ル系殺菌剤の中でも，一部に上記の問題が表面化しつつ あった，筆者らは，独創的で，高性能の薬殽によってこれ らの問題を解決すべく, 合成手法と計算化学的手法を駆使 し, 新規アゾール系殺菌剤の探索研究に着手した。本稿で は，イプコナゾールとメトコナゾール (Fig. 1) の研究の経 緯などについてその概要を紹介する。

\section{研究の経 緯}

\section{1. 背景と目標}

アゾール系殺菌剤は, 抗菌スペクトルの広さと優れた浸 透移行性により農業分野では, 不可欠の一群になっている. また植物病原菌の菌体膜構成成分であるエルゴステロール 生合成の C-14 脱メチル化酵素チトクローム $\mathrm{P}^{4} 50_{14 \mathrm{DM}}$ を阻
害する農薬として知られている，本系統化合物の開発研究 は世界中の研究者が活発に手がけてきており，今までに 25 種以上の同系統薬剤が農業市場に参入している ${ }^{1,2)}$.

筆者らは，新規骨格のアゾール系殺菌剤を創製するにあ たって, 薬物と受容体の相互作用様式を想定し, 既知アゾー ル系殺菌剤の構造と活性の相関を新たな視点から考之分子 設計を行った.

\section{2. 分子設計の発想}

アゾール系殺菌剤の多くは, 化学構造の特徵としてア ゾール環とベンゼン環を持っている，さらに，水酸基を有 する場合が多い.アゾール環とベンゼン環を結ぶ結合数の 違いからアゾール系殺菌剤を分類した場合，それらの多く は，2結合タイプか 3 結合夕イプに分類される(Fig. 2). 既 知アゾール系殺菌剤の構造を 3 次元的視点で見てみると, 活性発現に必須と考えられるアゾール環とベンゼン環は, 親油的な基を介して互いに逆方向に位置していることに着 目した。もし，アゾール環とベンゼン環が Fig. 3 に模式的 に示したように，それぞれの芳香環に対応するチトクロー 么 $\mathrm{P}^{4} 50_{14 \mathrm{DM}}$ の相互作用部位に適合するならば, 高活性が期 待できると考えた。

芳香環間の距離を制限するために親油性基（母核）とし て環状構造（Fig. 3 の A 部分）を設定した。環状構造とし 


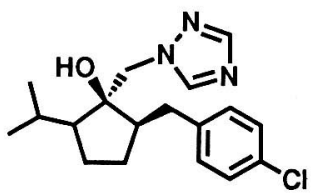

ipconazole $\left(\right.$ Techlead $^{\circledR}$ )

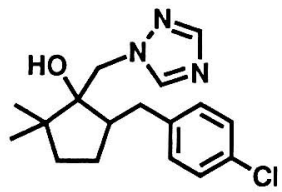

metconazole $\left(\right.$ CARAMBA $^{\circledR}$ )
Fig. 1 Chemical structures of ipconazole and metconazole.

Two-bond type :
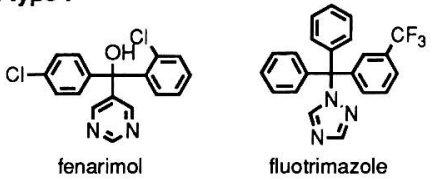

Three-bond type :
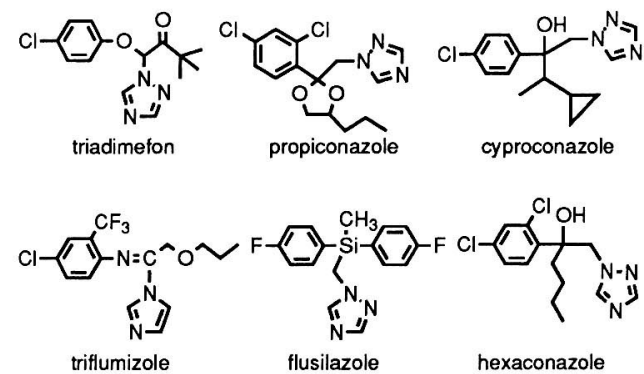

Fig. 2 Typical azole type fungicides for agricultural use.

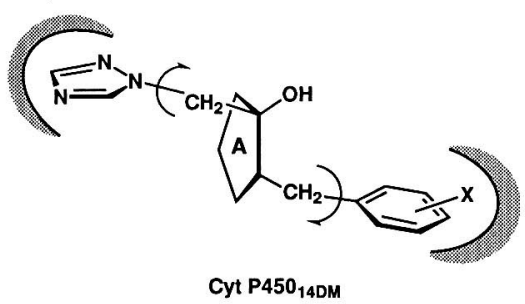

Fig. 3 Hypothetical binding model of our conceptional lead molecule to the target enzyme cytochrome $\mathrm{P} 450_{14 \mathrm{DM}}$.

て具体的にはシクロペンタン環を選定した。この理由はシ クロペンタン環の配座がシクロへキサン環などに比較して 柔軟であるために，環構造によって制限された芳香環間の 距離に一定の許容範囲を与えることによる。ささらに，シク ロペンタン環とアゾール環およびベンゼン環の間に炭素を 一つずつ挿入した。これにより，シクロペンタン環の効果 に加えて，芳香環間の距離と配向の自由度を大きくし，対 応する相互作用部位への二つの芳香環の微妙な適合の可能 性を高められると考えた。また他のアゾール系殺菌剂の構 造との比較から，水酸基をアゾリルメチル基と同位置へ導 入した ${ }^{3-6)}$.

以上のような発想の下で, アゾール環とベンゼン環を 5
本の結合で結び，その間にシクロペンタン環を配するとい うュニークな構造のアゾール系シクロペンタノール誘導体 type I 設計し，Fig. 4 に示した方法で合成した7).

\section{3. リード化合物の発見と定量的構造活性相関解析}

type I の殺菌活性を評価した結果, ムギ類のさび病, うど んこ病，イネばか苗病，ならびに灰色かじ病に対して高い 活性を示し, 抗菌スペクトルの広い化合物群であることが 明かとなった。これら誘導体の灰色かび病菌のステロール 生合成への影響を調べたところ，顕著なエルゴステロール の減少と 24-メチレンジヒドロラノステロールの蓄積が認 められ，想定どおりエルゴステロール生合成経路の C-14 脱メチル化を阻害する㘊であることが確認された。 type I の構造と活性を検討したところ, 水酸基とベンジル基の相 对配置に関しては，シス型がトランス型より活性が高いこ とがわかった．また，アゾール基に関しては，in vivo 試験 ではトリアゾール基置換体が，イミダゾール基置換体より も活性が高かったので，以後すべてトリアゾール基置換体 の活性を評価した. type I の構造と in vitro 試験における灰 色かび病菌 Botrytis cinerea とイネばか苗病菌 Gibberella fujikuroi に対する殺菌活性の相関について, 物理化学的パ ラメータおよび置換ベンゼン環上の立体形状パラメータを 用いて Hansch-Fujita 法による定量的構造活性相関解析を 行い式（1），(2) を得た。ベンゼン環の立体形状パラメー 夕については, ベンゼン環の中心を原点とし，結合軸方向 にX 軸をとり，それと垂直方向に $\mathrm{Y}$ 軸をとった. 置換ベン ゼン環の $\mathrm{Y}$ 軸方向の長さを $W$ とし, 原点から metapara-位置換基までの $\mathrm{X}$ 軸方向の長さを $L_{1}$, 原点から ortho-位置換基までの X 軸方向の長さを $L_{2}$ とした. $\mathrm{Z}$ 軸方 向の置換ベンゼン環の厚みを $D$ とした ${ }^{3)}$ (Fig. 5).

$$
\begin{aligned}
\mathrm{pIC}_{50} \text { (Botrytis cinerea in vitro) } & -1.309 L_{2}-0.843 W-0.716 D+4.023 \log P \\
& -0.541(\log P)^{2}+10.068 \\
& \left(n=18, r=0.952, s=0.282, \log P_{\mathrm{opt}}=3.71\right)
\end{aligned}
$$

$$
\begin{aligned}
& \mathrm{pIC}_{50} \text { (Gibberella fujikuroi in vitro) } \\
& \begin{aligned}
= & -0.833 L_{2}-0.711 W-0.435 D+2.896 \log P \\
& -0.356(\log P)^{2}+8.735 \\
& \left(n=16, r=0.938, s=0.237, \log P_{\mathrm{opt}}=4.07\right)
\end{aligned}
\end{aligned}
$$

ここでは， $\mathrm{pIC}_{50}$ は菌系伸長を $50 \%$ 阻害するモル濃度 $(\mathrm{mol} /$ 1)の逆数の対数值, $n$ は化合物数, $r$ は相関係数, $s$ は標準 偏差を表す。

活性は，化合物の親踈水性尺度 $\log P$ 値に依存し，その 最適値は, 灰色かび病菌で 3.71 , イネばか苗病菌で 4.07 で あることが示された．また式 (1)，(2) 共に $L_{2}, W ， D$ の 各係数が負であることは, ベンゼン環の para-位以外に置 
Synthetic method for intermediate (4)

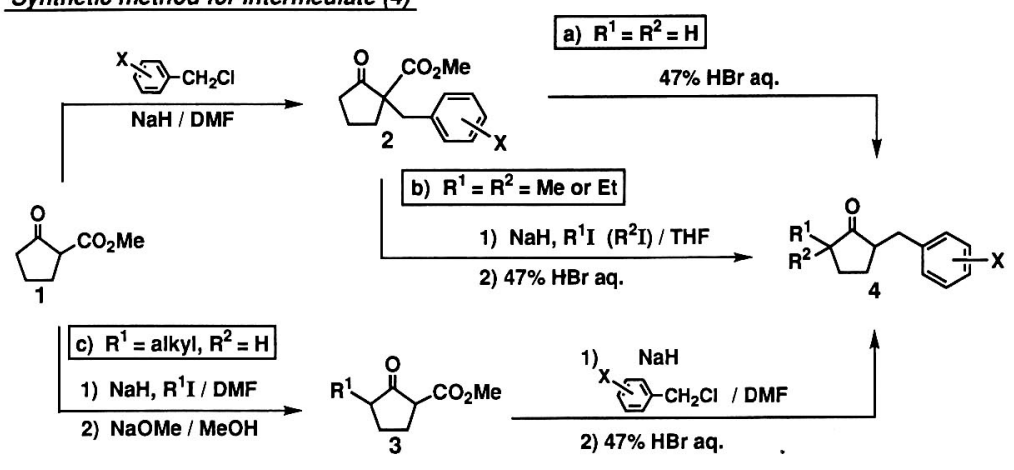

Synthetic method for type I, II

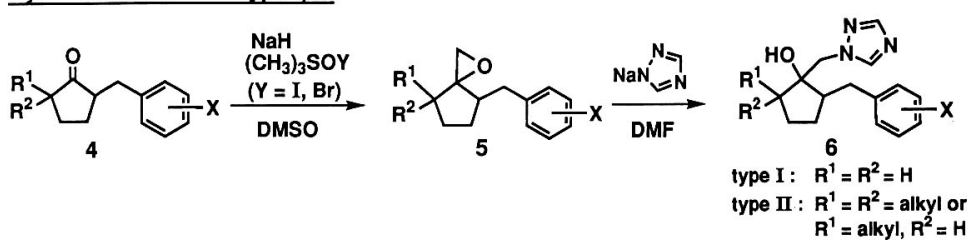

Fig. 4 Synthetic scheme for azolylmethylcyclopentanols (type I, II).

換基が存在したり，かさ高い置換基があると活性が低下す ることを示している．なお，統計的に Hammett $\sigma$ などの電 子的パラメー夕の有意性は認められなかった。

次に，in vivo 試験におけるキュウリを用いた灰色かび病 に対する殺菌活性について解析して，式(3)を得た。

$$
\begin{aligned}
& \mathrm{pIC}_{50} \text { (Botrytis cinerea in vivo) } \\
& =-1.090 \mathrm{~W}+5.781 \log P-1.008(\log P)^{2}+2.624 \\
& \quad\left(n=18, r=0.854, s=0.425, \log P_{\mathrm{opt}}=2.87\right)
\end{aligned}
$$

$\log P$ の最適值は 2.87 であり, in vitro 試験の結果と比べ ると 0.8 低い值である。これは化合物の植物体への浸透移 行性に関係していると考之ている. $W$ の係数が負であるこ とより in vitro 試験の場合と同様に, ベンゼン環の para-位 以外に置換基が存在すれば活性が低下することが示され た. type Iの中で市販アゾール剤と同等の高活性を有する para-Cl 体（KNF-508）をリード化合物として選択した。

\section{4. メトコナゾールの発見}

リード化合物 KNF-508 の活性をさらに上げるため, 以 下に述べる物理化学的な検討を行った. typeI の構造活性相 関式 (1)，(2) から最適 $\log P$ 值が 3.7〜 4.0 付近にあり, 他社の幾つかのアゾール系殺菌剂の $\log P$ 值は $3.1 \sim 4.5$ の 範囲（平均值 4.0）であること, 分子容 (van der Waals 体 積)の平均值は $280 \AA^{3}$ であること, 一方 KNF-508のそれぞ れの值は 3.11, $260 \AA^{3}$ であることを考虑して, KNF-508に 上記の条件を満たすようなアルキル基を導入することを検 討した ${ }^{3,4)}$. 構造活性相関式(1), (2)より, ortho-, metha位への置換基導入や, para-位へのかさ高い置換基導入は,
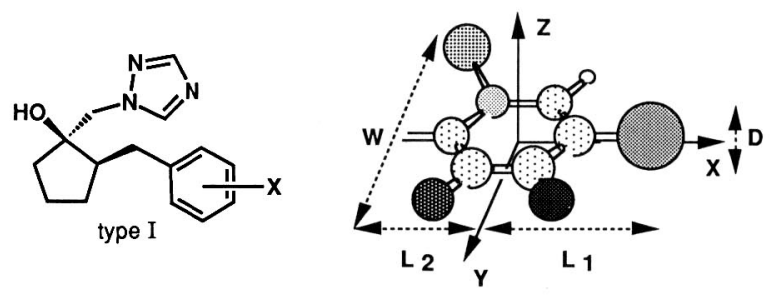

Fig. 5 Steric parameters for substituted phenyl moiety.

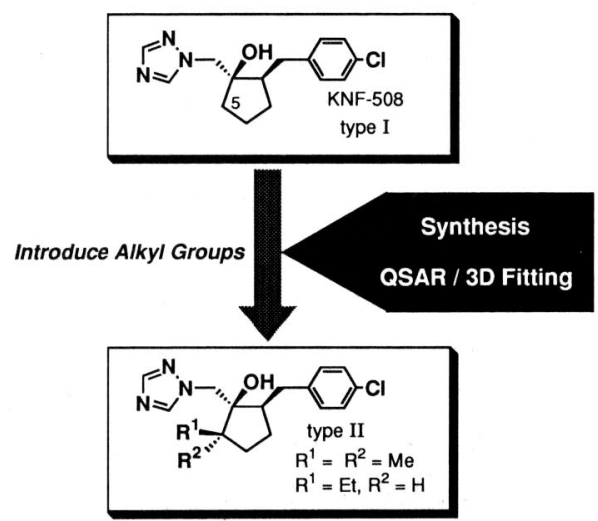

Fig. 6 Molecular design of metconazole from lead compound KNF-508.

活性を低下させることから，アルキル基の導入はシクロペ ンタン環上が望ましいと考えた。導入位置として，KNF508 の合成中間体を利用できるアゾリルメチル隣接位（シ クロペンタン環 5 位) を選び，化合物 type II の合成に着手 すると同時にその 3 次元立体構造を他社の幾つかのアゾー 

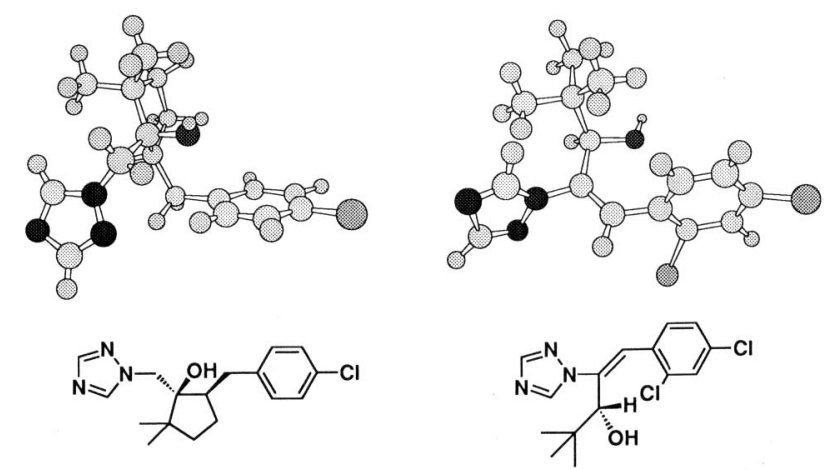

Fig. 7 Three-dimensional shape comparison of $(-)-(1 S$, $5 R)$-metconazole (left) and (-)-( $R)$-diniconazole (right).

Table 1 Fungicidal activity of stereoisomers of KNF-508 (lead compound) and metconazole in vitro.

\begin{tabular}{lcc}
\hline \multirow{2}{*}{ Compound } & \multicolumn{2}{c}{$\mathrm{EC}_{90}(\mathrm{mg} / 1)^{\mathrm{a})}$} \\
\cline { 2 - 3 } & B.c. & G.f. $f^{\mathrm{b})}$ \\
\hline KNF-508 cis & 0.9 & 2.1 \\
KNF-508 trans & 32.1 & 152 \\
metconazole cis & 0.2 & 0.2 \\
metconazole trans & 1.8 & 2.0 \\
(+)-metconazole cis & 10.0 & 20.0 \\
(-)-metconazole cis & 0.1 & $<0.1$ \\
\hline
\end{tabular}

a) Effective concentration of $90 \%$ inhibition of mycerial

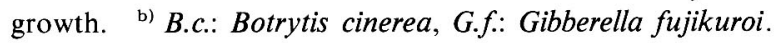

ル系殺菌剤の立体構造と比較検討した(Fig.6). type II の化 合物は, type I と同様な方法で調達した ${ }^{8)}$ (Fig. 4).

他社アゾール剂との 3 次元立体構造比較の一例としてジ ニコナゾール (住友化学) との比較結果を Fig. 7 に示す. ジニコナゾール活性配置体 $(-)-(R)-$ 体とリード化合物 KNF-508 のシクロペンタン環 5 位にジメチル基を導入し, 後にメトコナゾールと命名した化合物とを解析した結果, それぞれの分子のアゾール環，ベンゼン環との間の結合数 が異なる（メトコナゾール＝5，ジニコナゾール＝3）にも かかわらず, 全体的にも，また導入したジメチル基がジニ コナゾールの $t$-ブチル基部分に良好に対応することが分 かった。この結果は KNF-508のシクロペンタン環 5 位に 導入したアルキル基部分が単に疎水性, 分子容の増大から の寄与のみならず，受容体の活性部位へ直接的に作用し殺 菌活性向上に関与することを示している.メトコナゾール を含む幾つかの type II の合成が完了し，それらの殺菌活性 を測定した結果, type II は type Iに比較して大幅な活性上 昇を示したままた，メトコナゾールの光学活性体について は，(）-体が (+)-体に比べはるかに高い活性を示した (Table 1)。この結果はジニコナゾールとの立体構造比較か ら予想したアルキル基の活性への寄与とともにメトコナ
ゾールの予測活性絶対立体配置 $(-)-(1 S, 5 R)$ が正しかっ たことを意味する。

type II 化合物群の大幅な殺菌活性向上を確認した後，ア ルキル基の殺菌活性に対する効果を再度 Hansch-Fujita 法 を用いて解析した. type Iの解析に用いたパラメータに加 え, シクロペンタン環上のアルキル基 $\left(\mathbf{R}^{1}, \mathbf{R}^{2}\right)$ の有無を表 す indicator variable $I\left(\mathrm{R}^{1}=\mathrm{R}^{2}=\mathrm{H}\right.$ の場合 $I=0$ ， その他の 場合 $I=1$ ) を導入し, type I に type II を加えた化合物群に ついての解析を行い, 次式 (4)，（5）を得た.

$$
\begin{aligned}
\left.\mathrm{pIC}_{50} \text { (Botrytis cinerea in vitro, type } \mathrm{I}+\text { type } \mathrm{II}\right) \\
=-0.761 L_{2}-0.862 W-0.669 D+3.237 \log P \\
-0.418(\log P)^{2}+0.428 I+9.782 \\
\quad\left(n=32, r=0.933, s=0.377, \log P_{\mathrm{opt}}=3.87\right)
\end{aligned}
$$

$\mathrm{pIC}_{50}$ (Gibberella fujikuroi in vitro, type I+type II)

$$
\begin{aligned}
= & -0.790 W-0.270 D+3.350 \log P \\
& -0.471(\log P)^{2}+1.012 I+6.14 \\
& \left(n=30, r=0.966, s=0.245, \log P_{\mathrm{opt}}=3.56\right) .
\end{aligned}
$$

式（4)，（5）は，typeIのそれぞれに対応する式（1)，(2) と比較して, 各説明変数の係数の符号, 大きさが類似して いた。また，indicator variable $I$ が統計的に有意であるこ とは，アルキル基が活性上昇に大きく寄与していることを 表している.

3 次元立体構造の比較検討ならびに Hansch-Fujita 法に よって得られた結果はともにシクロペンタン環上のアルキ ル基が標的酵素チトクローム $\mathrm{P} 450_{14 \mathrm{MD}}$ との相互作用にお いて重要な相互作用部位であることを示唆している。この 研究の間に筆者らの開発した新規な 3 次元構造活性相関解 析法 Voronoi Field Analysisによっても，このアルキル基 がチトクローム $\mathrm{P}^{4} 50_{14 \mathrm{DM}}$ との疎水性相互作用部位である ことが示された ${ }^{10)}$.

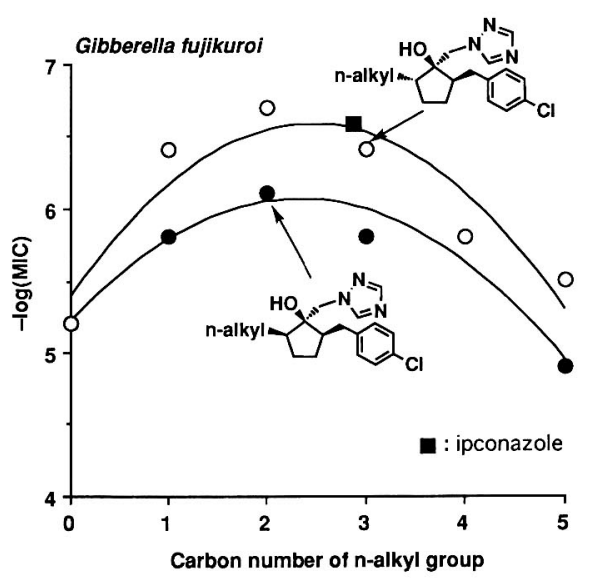

Fig. 8 Correlation of fungicidal activity with carbon number of 5-monoalkylazolylmethylcyclopentanols. 

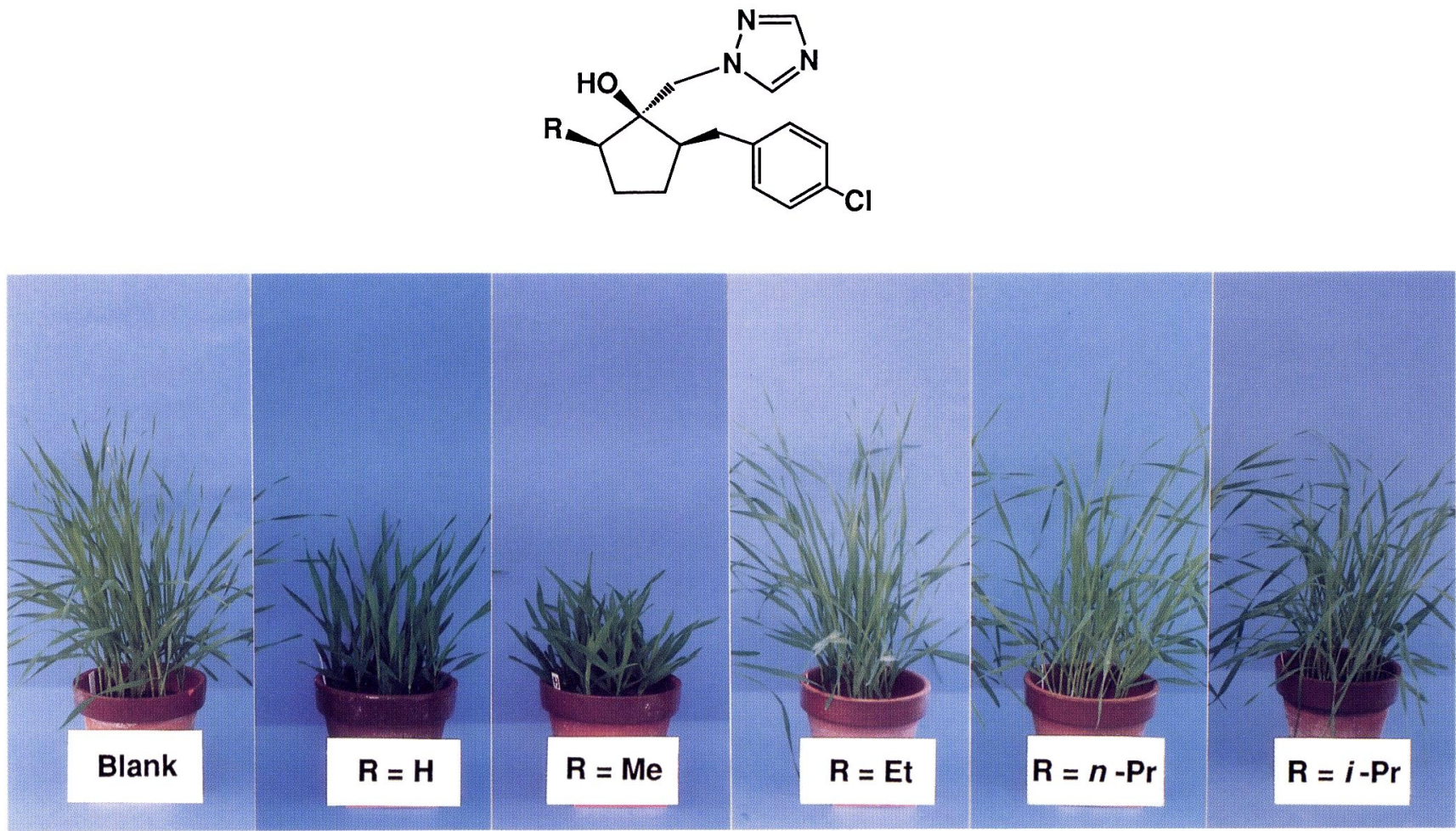

Fig. 9 Plant growth regulatory activity of 5-monoalkylazolylmethylcyclopentanols on wheat.

Wheat seeds were soaked in the suspension containing $250 \mu \mathrm{g} / \mathrm{ml}$ of each test compound for 24 hr and grown in greenhouse for 3 weeks.

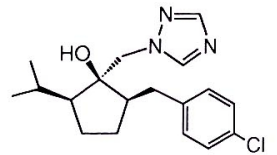

ipconazole $\mathrm{cc}^{\text {a) }}$

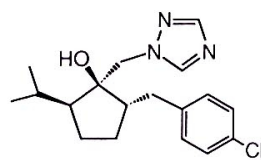

ipconazole $\mathrm{tc}^{\text {a) }}$

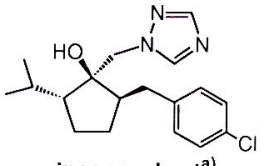

ipconazole $\mathrm{ct}^{\mathrm{a})}$

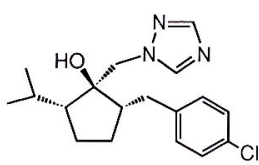

ipconazole $t^{\text {a) }}$

Fig. 10 Structures of ipconazole and its stereoisomers. a) The first c(cis) or t(trans) indicates the configuration with respect to the hydroxy group and the benzyl group, and the second $\mathrm{c}($ cis $)$, or t(trans) indicates the configuration with respect to the hydroxy group and alkyl substitution on the cyclopentane ring.

\section{5 員環のジメチル位置異性体の構造と活性}

活性向上に大きく寄与するメトコナゾールのシクロペン タン環 2 位のジメチル基が，最適な置換位置であるかを調 べるために，ジメチル基を 3 または 4 位に置換させた化合 物を合成し殺菌活性を評価した。その結果, 2 位のジメチル 基置換体であるメトコナゾールは，3 または 4 位置換体と 比較してはるかに高い活性を有しており，ジメチル基の位 置としては最適であることが改めて確涩された ${ }^{11}$.

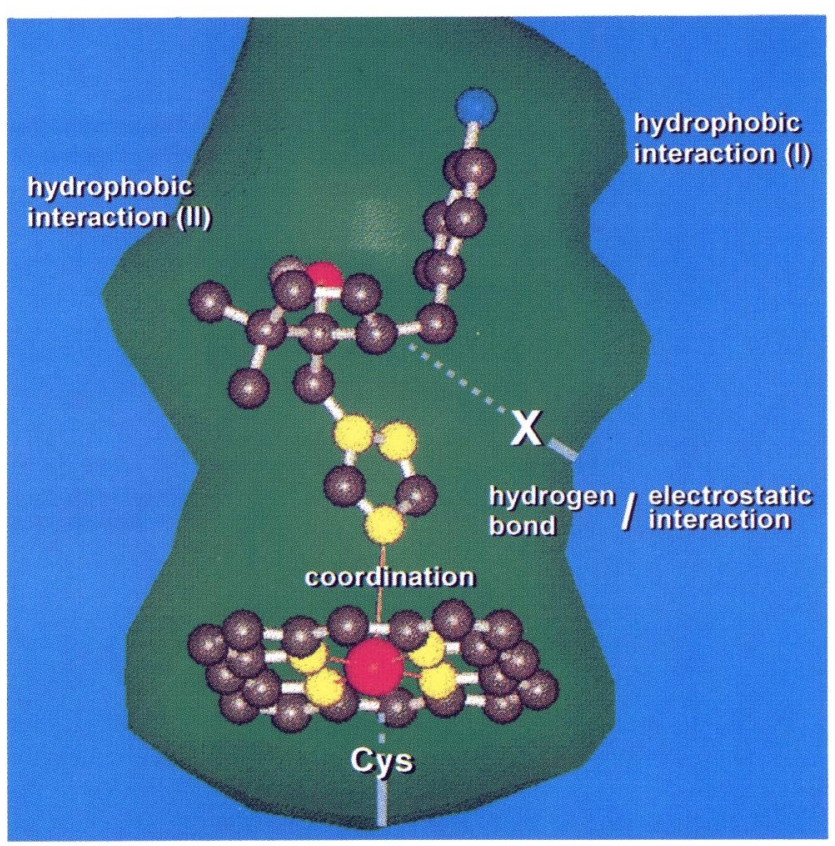

Fig. 11 Schematic diagram illustrating the binding of $(-)$ $(1 S, 5 R)$-metconazole to cytochrome $\mathrm{P} 450_{14 \mathrm{DM}}$

\section{6. シクロアルカン誘導体の構造と活性}

母核の環構造としてシクロペンタン環を採用したが，シ クロヘキサン環やシクロへプタン環母核の化合物はどの程 
度の殺菌活性を有しているのか興味が持たれた。メトコナ ゾールのシクロペンタン環部をシクロヘキサン環, シクロ ヘプタン環に置き換えた化合物を合成し殺菌活性を調べ た。シクロへプタン誘導体は，メトコナゾールより低下し， シクロヘキサン誘導体は更に低下した。シクロアルカノー ル誘導体のベンゼン環とトリアゾール環の空間配置を配座 解析をした結果，シクロアルカノール誘導体間で異なって いることが示された ${ }^{12)}$.

\section{7. イプコナゾールの発見}

リード化合物 KNF-508 のシクロペンタン環 5 位へのア ルキル基導入が，殺菌活性を大きく左右することが示唆さ れたために，さらに炭素数の異なるモノアルキル基を導入 し，構造と活性の関係をさらに検討した。そのの結果，アル キル炭素数と殺菌活性との間に Fig. 8 に示したような関係 が見られ, 炭素数が 2 個 3 個の場合に, 高い殺菌活性を示 すことが分かった ${ }^{4,11}$. さらに，アゾール剂特有の植物生長 調節作用（矮化作用）を調べた結果，モノメチル置換体は 無置換体よりも強い矮化作用を示したが, エチル置換体, イソプロピル置換体， $n$-プロピル置換体など，アルキル炭 素数が 2 個以上の誘導体からは，その矮化作用は劇的に消 失した ${ }^{11,13)}$ (Fig. 9)。 また， ジメチル置換体であるメトコナ ゾールの矮化作用はモノメチル置換体と同等であり, 同じ 炭素数のエチル置換体の作用よりもはるかに強いことか ら，植物の矮化作用はこの部位のアルキル鎖の長さが大き く影響していることが明かとなった。

イプコナゾールの有効成分は，二つの幾何異性体である イプコナゾール cc とイプコナゾールct から成り立ってい る (c と t の意味は Fig. 10 に記載)。その他に 2 種の幾何異 性体イプコナゾール tc とイプコナゾール tt がある. 有効成 分の 2 種とイプコナゾール $\mathrm{tt} の$ 殺菌活性はほぼ同等で あったが，イプコナゾール tc の活性は劣った ${ }^{14)}$ (Table 2).

これらモノアルキル誘導体と合成した全てのシクロペン タノール誘導体の中から実用性評価を進めた結果，イプコ ナゾールはイネばか苗病，イネいもち病，イネごま葉枯病

Table 2 Fungicidal activity of ipconazole racemic diastereomers in vitro.

\begin{tabular}{llll}
\hline \multirow{2}{*}{ Compound } & \multicolumn{3}{c}{$\mathrm{EC}_{50}(\mathrm{mg} / 1)^{\mathrm{a})}$} \\
\cline { 2 - 4 } & G.f. & C.m. & P.o. $^{\text {b) }}$ \\
\hline ipconazole cc & 0.05 & 0.4 & 0.08 \\
ipconazole ct & 0.06 & 0.4 & 0.03 \\
ipconazole tc & 0.9 & 1 & 0.5 \\
ipconazole tt & 0.09 & 0.5 & 0.04 \\
\hline
\end{tabular}

a) The effective concentration of $50 \%$ inhibition of mycerial growth value on the PSA after incubation for 3 days at 28 ${ }^{\circ} \mathrm{C}$. ${ }^{\text {b) }}$ G.f.: Gibberella fujikuroi, C.m.: Cochliobolus miyabeanus, P.o.: Pyricularia oryzae.
に優れた効果を示したことから，イネ種子消毒剂として開 発が進められた．また，メトコナゾールは欧州のムギ病害 を対象とする殺菌剂として選抜された。

\section{8. チトクローム $\mathbf{P 4 5 0}_{14 \mathrm{DM}}$ との相互作用様式}

メトコナゾールとイプコナゾールの発見の過程で合成さ れた誘導体の構造活性相関解析と 3 次元立体構造解析か ら，それらの受容体であるチトクローム $\mathrm{P}^{4} 50_{14 \mathrm{DM}}$ との相互 作用様式を考察した。その推定相互作用様式の模式図を Fig. 11 に示した。 1) トリアゾール環は $\mathrm{P} 450_{14 \mathrm{DM}}$ のへム鉄 一配位する．2)べンゼン環は疎水性相互作用部位と推定さ れ，para-位にかさ高さの小さい置換基が活性に有利．3) シクロペンタン環上の 2 位のアルキル基はもう一つの疎水 性相互作用部位と推定され，アルキル基の炭素数 2 個 3 個の場合が最適と考えられる．4) 水酸基は特定の位置での 水素結合あるいは静電相互作用部位と推定される ${ }^{3,4,11,15)}$.

\section{工業化}

イプコナゾールとメトコナゾールは, Fig. 4 に示した中 間体ケトン $(\mathbf{4})$ から，オキシラン化，アゾール化を経るルー 卜によって製造される ${ }^{8.16)}$.オキシラン化工程にジメチルス ルホキソニウムメチリド（イリド）を使用することにより， 両剤ともに，より高活性なベンジル基がシス型の異性体が 優先的に得られる.イリドの原料である Corey 試薬は, 経 済性のあるトリメチルスルホキソニウムブロミドの商用プ ロセスを確立し，イプコナゾールとメトコナゾールの製造 を支えている。

\section{名称および性状 ${ }^{17)}$}

一般名：イプコナゾール (ipconazole), 商品名：テク リート , 化学名 (IUPAC) : $(1 R S, 2 S R, 5 R S ; 1 R S, 2 S R$, 5SR)-2-(4-chlorobenzyl)-5-isopropyl-1-(1 H-1,2,4-triazol-1ylmethyl)cyclopentanol, 分子式： $\mathrm{C}_{18} \mathrm{H}_{24} \mathrm{ClN}_{3} \mathrm{O}$, 外観：白色 結晶, 融点: $88-90^{\circ} \mathrm{C}$, 分配係数: $P_{\mathrm{ow}}=1.76 \times 10^{4}(\log P=$ $4.24)$, 水溶解度 : $6.93 \mathrm{mg} / 1\left(20^{\circ} \mathrm{C}\right)$

一般名：メトコナゾール (metconazole), 商品名: CARAMBA ${ }^{\circledR}$, 化学名(IUPAC) : (1RS, 5RS; 1RS, 5SR)-5-(4chlorobenzyl)-2,2-dimethyl-1-(1 H-1,2,4-triazol-1-ylmethyl) cyclopentanol, 分子式： $\mathrm{C}_{17} \mathrm{H}_{22} \mathrm{ClN}_{3} \mathrm{O}$, 外観：白色結晶, 融 点： $110-113^{\circ} \mathrm{C}$, 分配係数： $P_{\mathrm{ow}}=7.08 \times 10^{3}(\log P=3.85)$, 水溶解度: $15 \mathrm{mg} / 1\left(20^{\circ} \mathrm{C}\right)$

\section{生 物 活 性}

\section{1. 基礎活性}

イプコナゾールおよびメトコナゾールは子囊菌類, 担子 菌類, 不完全菌類の中の多くの菌類に高い殺菌活性を示し, 特に, Gibberella, Botrytis, Sclerotinia, Fusarium, Alternaria, 
Table 3 Fungicidal activity of ipconazole and metconazole.

\begin{tabular}{|c|c|c|}
\hline \multirow{2}{*}{ Test fungi } & \multicolumn{2}{|c|}{$\operatorname{MIC}(\mathrm{mg} / 1)^{\mathrm{a})}$} \\
\hline & Ipconazole & Metconazole \\
\hline \multicolumn{3}{|l|}{ Ascomycotina } \\
\hline Cochliobolus miyabeanus & 50 & 25 \\
\hline Gibberella fujikuroi & 0.5 & 0.5 \\
\hline Gibberella zeae & 1.6 & 3.1 \\
\hline Glomerella cingulata & 1.6 & 1.6 \\
\hline Leptosphaeria nodorum & 0.8 & 0.8 \\
\hline Monilinia mali & 0.02 & 0.05 \\
\hline Pyrenophora graminea & 13 & 13 \\
\hline Sclerotinia cinerea & 0.05 & 0.1 \\
\hline Valsa ceratosperma & 0.1 & 0.2 \\
\hline \multicolumn{3}{|l|}{ Basidiomycotina } \\
\hline Corticium rolfsii & 1.6 & 6.3 \\
\hline Ustilago nuda & 3.1 & 6.3 \\
\hline \multicolumn{3}{|l|}{ Deuteromycotina } \\
\hline Alternaria kikuchiana & 6.3 & 6.3 \\
\hline Alternaria mali & 25 & 25 \\
\hline Alternaria padwickii & 3.1 & 3.1 \\
\hline Botrytis cinerea & 0.8 & 0.8 \\
\hline Cercospora beticola & 1.6 & 1.6 \\
\hline Colletotrichum lagenarium & 1.6 & 13 \\
\hline Fusarium nivale & 13 & 50 \\
\hline Fusarium oxysporum $f$. sp. niveum & 6.3 & 3.1 \\
\hline Fusarium roseum $f$. $\mathrm{sp}$. cerealis & 1.6 & 1.6 \\
\hline Fusarium solani & 13 & 6.3 \\
\hline Helminthosporium sigmoideum & 1.6 & 25 \\
\hline Penicillium digitatum & 0.2 & 0.2 \\
\hline Penicillium italicum & 1.6 & 3.1 \\
\hline Pseudocercosporella herpotrichoides & 0.8 & 0.8 \\
\hline Pyricularia oryzae & 1.6 & 1.6 \\
\hline Septoria tritici & 0.05 & 0.1 \\
\hline Trichoderma viride & 1.6 & 1.6 \\
\hline Verticillium dahliae & 1.6 & 1.6 \\
\hline \multicolumn{3}{|l|}{ Zygomycotina } \\
\hline Mucor fragilis & 25 & 25 \\
\hline Rhizopus oryzae & 0.2 & 3.1 \\
\hline
\end{tabular}

${ }^{\text {a) }}$ MIC was measured on potato sucrose agar medium.

Table 4 Effect of ipconazole against rice seed-borne diseases.

\begin{tabular}{|c|c|c|c|c|}
\hline \multirow{3}{*}{$\begin{array}{l}\text { Fungicides and } \\
\text { application methods }\end{array}$} & \multicolumn{4}{|c|}{ Control \% ${ }^{\mathrm{a})}$} \\
\hline & \multicolumn{2}{|c|}{ Bakanae diseae } & \multirow[b]{2}{*}{ H. leaf spot $^{\text {d) }}$} & \multirow[b]{2}{*}{ Blast $^{\mathrm{e})}$} \\
\hline & BI-sensitive ${ }^{\mathrm{b})}$ & BI-resistant ${ }^{\mathrm{c})}$ & & \\
\hline \multicolumn{5}{|l|}{ ipconazole 6\% WP } \\
\hline 200 -fold, $24 \mathrm{hr}$ dip & 100 & 99 & 100 & 98 \\
\hline 20 -fold, $10 \mathrm{~min}$ dip & 100 & 99 & 97 & 100 \\
\hline $0.5 \%$ wetted dressing & 99 & - & - & - \\
\hline 7.5 -fold $3 \%$ spray & 100 & - & - & - \\
\hline \multicolumn{5}{|l|}{ thiram-benomyl WP } \\
\hline 200 -fold, $24 \mathrm{hr}$ dip & 99 & 18 & 43 & 97 \\
\hline 20 -fold, $10 \mathrm{~min}$ dip & - & 51 & 88 & - \\
\hline untreated $^{\mathrm{f})}$ & $(26.4)$ & $(56.8)$ & $(9.4)$ & $(10.0)$ \\
\hline
\end{tabular}

a) Based on percentage of diseased seedlings of untreated reference. Mean value of tree replications. b) Rice plant, cv. Tanginbozu, was inoculated with conidial suspension of benzimidazole-sensitive isolate at flowering stage. ${ }^{c)}$ Rice plant, cv. Tanginbozu, was inoculated with conidial suspension of benzimidazole-resistant isolate at flowering stage. d) Rice plant, cv. Yamahoushi, Helminthosporium leaf spot naturally infected seeds. ${ }^{\text {e) }}$ Rice plant, cv. Sasanishiki, blast naturally infected seeds. ${ }^{f)}$ Incidence of diseased seedlings (\%) for Bakanae disease and blast. For Helminthosporium leaf spot, Index of incidence $=[(4 \times$ $\left.\left.n_{4}+3 \times n_{3}+2 \times n_{2}+n_{1}\right) /(4 \times N)\right] \times 100$. $n_{\mathrm{x}}:$ number of seedlings with disease at following locations. $n_{1}$ : the first leaf sheath. $n_{2}$ : within the second leaf. $n_{3}$ : within the third leaf. $n_{4}$ : damping-off. $N$ : total number of seedlings. 
Table 5 Fungicidal activity of metconazole against Septoria spp. on wheat.

\begin{tabular}{|c|c|c|c|c|}
\hline \multirow{2}{*}{ Treatment } & \multirow{2}{*}{$\begin{array}{c}\text { Dose } \\
\text { g a.i./ha }\end{array}$} & \multicolumn{3}{|c|}{ Average control (\%) on leaves 1 and 2} \\
\hline & & S. tritici $^{\text {a) }}$ & $L$ & $u m^{\mathrm{b})}$ \\
\hline metconazole & 48 & 81 & - & - \\
\hline metconazole & 60 & 83 & - & - \\
\hline metconazole & 70 & 87 & 84 & 53 \\
\hline metconazole & 90 & - & 87 & 62 \\
\hline standard $\mathrm{A}^{\mathrm{c})}$ & 250 & 82 & 86 & 65 \\
\hline standard $\mathrm{B}^{\mathrm{c})}$ & 100 & 82 & - & - \\
\hline standard $C^{d)}$ & $200+100$ & - & 84 & - \\
\hline untreated (\% infection) & & $(60)$ & $(39)$ & $(28)$ \\
\hline country & & U.K. & France & Germany \\
\hline number of trials & & 8 & 9 & 5 \\
\hline years & & '91\&'92 & '92 & '91\&92 \\
\hline
\end{tabular}

a) Septoria tritici. b) Leptosphaeria nodorum. ${ }^{\text {c) }}$ other triazole type fungicides. ${ }^{\text {d) }}$ other triazole type fungicide + benzimidazole type fungicide.

Septoria などに高い活性を有することが特徴である ${ }^{18,19)}$ (Table 3). 両剤とも殺菌スぺクトルには大きな違いはない が，植物生長調節活性が異なり，それが両剂の適用場面を 分けている主な理由となっている。

\section{2. 畨場試験活性}

イプコナゾールはイネの種子伝染病害として重要なイネ ばか苗病，いもち病，ごま葉枯病や，トリコデルマやリゾ プスによる苗立枯病などに高い防除効果を示し，さらに作 物に対して高い安全性を有することから，イネ種子消毒に 有効な薬剂である ${ }^{20)}$. また, ベンズイミダゾール系耐性菌, および一部のアゾール剂の低感受性菌にもその高い殺菌活 性から十分な防除効果が得られた ${ }^{21)}$ (Table 4). 一方, メト コナゾールは $90 \mathrm{~g} / \mathrm{ha}$ 以下の低薬量でムギ茎葉病害の赤さ び病, 黄さび病, セプトリア病, 穂のフザリウム病などに 高い予防効果と治療効果を有する ${ }^{19,22)}$ (Table 5). 本剂は ヨーロッパのムギ病害防除体系の中期, 後期処理で重要な さび病，セプトリア病，フザリウム病に特に優れている. さらに, ナタネの黒斑病や菌核病にも適用が広がり，その 微妙な植物生長抑制作用による倒伏防止効果も相まって大 幅な収量増加をもたらすことが見いだされている。

\section{安 全 性}

\section{1. 人畜毒性と環境生物への影響}

イプコナゾールおよびメトコナゾールの急性毒性は, 経 ロ (ラット雄) $\mathrm{LD}_{50}$ は，それぞれ $1338 \mathrm{mg} / \mathrm{kg}, 1459 \mathrm{mg} / \mathrm{kg}$, 経皮（ラット） $\mathrm{LD}_{50}$ は共に $2000 \mathrm{mg} / \mathrm{kg}$ 以上，皮膚刺激性 (ウサギ）は共に弱い刺激性，皮膚感作性（モルモット）と 変異原性（Ames）は共に陰性であった ${ }^{19,20)}$. いずれの剂も 哺乳動物へは普通物，魚毒性は B 類に相当する. 鳥類, ミ
ツバチ，ミミズなどへの毒性も低く，通常の使用法では使 用薬量が少ないこともあって, 環境への負荷が低い剂であ る。

\section{2. 代謝分解と環境中での挙動}

イプコナゾールは，種子処理において根部から茥葉部へ 移行しにくく，その分解は緩慢であった. 可食部（玄米） への移行, 残留は認められなかった ${ }^{23)}$.メトコナゾールは, 茎葉処理において茥葉部から可食部への移行は認められ ず，比較的安定であった，両剂とも土壌移行性は小さく， 圃場における土壌分解は試験土堙によって異なるが比較的 すみやかであった。

\section{おわりに}

筆者らが，探索研究をスタートした 1985 年当時，アゾー ル系殺菌剂の開発研究は世界的にもピークが過ぎ漸減しつ つあるテーマであった，そのような研究環境の中で，あ之 て挑戦し, 仮説から出発し設計したアゾール系シクロペン タノール誘導体の中から，二つのアゾール系殺菌剂を上市 できたことは幸運であった. 合成グループ, 生物評価グルー プそして計算化学グループがそれぞれに，各専門分野に少 なからず精通し互いに信頼し合ったことが研究の持続へつ ながり，新農薬の創出へ結びついたともいえる.

イプコナゾールは，全国農業共同組合連合会ならびにク ミアイ化学工業株式会社の協力が実り, 1994 年にイネ種子 消毒剂として，テクリード®の商品名で上市に結び付ける ことが出来た。また国内のムギ種子消毒剂として 1999 年 12 月に登録を取得した. メトコナゾールはアメリカン・サ イアナミド社の協力で 1994 年ムギ茎葉散布剂として, フラ ンスでCARAMBA ${ }^{\circledR}$ の商品名で販売された.今後, 両剂と 
もに，それぞれ特徵ある活性を発展させ，世界の安定した 食糧生産に寄与することを期待している。

最後に, イプコナゾールの開発上市にあたり，ご指導とご支援 を賜りました日本植物防疫協会ならびに各試験機関の諸先生方 に，この場をかりて厚く御礼を申し上げます。また，イプコナ ゾールとメトコナゾールの創製・開発上市には, 筆者らの研究の みならず, 構造活性相関解析研究では京都大学名誉教授の藤田 稔夫先生, 代謝研究などでは理化学研究所微生物制御研究室主 任の山口勇先生, 山形大学名誉教授の小原平太郎先生, 山形大学 工学部教授の小野寺準一先生, $\mathrm{X}$ 線結晶構造解析研究では東北 大学理学部の甲干寿子先生ならびに尅羽化学の多くの研究・開 発・生産・営業の関係者の多大なる努力の成果として製品化でき たものであり，ここに深く感謝致します。

\section{引用 文 献}

1) W. Köller: "Target Sites of Fungicide Action," ed. by W. Köller, CRC Press, Boca Raton, pp. 119-206, 1992

2) K. H. Kuck: "Modern Selective Fungicides," ed. by H. Lyr, Gustav Fischer Verlag, Jena; Stuttgart; New York, pp. 205258,1995

3) H. Chuman, A. Ito, T. Saishoji \& S. Kumazawa: "Classical and 3D QSAR in Agrochemistry," ed. by C. Hansch \& T. Fujita, ACS Symposium Series 606, American Chemical Society, p. 171,1995

4) 熊沢 智-伊藤篤史・最勝寺俊英・中馬 寛：Japan Chemistry Program Exchange Newsletter 6(4), 3 (1995)

5) T. Fujita: Quant. Struct.- Act. Relat. 16, 107 (1997)

6) 高橋正明-志田隆文・熊沢 智・狩野 保-中馬 寛：日 化協月報 3 月号, 4 (1996)

7) 熊沢 智 - 伊藤篤史 - 佐藤宣夫 - 最勝寺俊英 - 浜田正弘 山崎詞朗・江成宏之 (迨羽化学) : 特公開昭 62-14967 号 (1987)（特公平 07-33949 号)

8）熊沢 智 - 清水 進 - 江成宏之 - 伊藤篤史 - 池田 進 - 佐 藤宣夫・最勝寺俊英 (吳羽化学) : 特公開昭 63-41476 号 (1988)（特公平 06-25140 号)

9) T.Katagi: J. Agric. Food Chem. 36, 344 (1988)

10) H. Chuman, M. Karasawa \& T. Fujita: Quant. Struct.-Act. Relat. 17, 313 (1998)

11）伊藤篤史・最勝寺俊英・熊沢 智・中馬 寞：第 22 回構造 活性相関シンポジウム講演要旨集, p. 230, 1994

12) A. Ito, T. Saishoji, S. Kumazawa \& H. Chuman: J. Pesticide Sci. 24, 262 (1999)

13) T. Saishoji, A. Ito, S. Kumazawa \& H. Chumann: $J$. Pesticide Sci. 23, 129 (1998)
14) A. Ito, T. Saishoji \& S. Kumazawa: J. Pesticide Sci. 22, 119 (1997)

15) 中馬 寛・伊藤篤史・最勝寺俊英・熊沢 智：農薬誌 23, $330(1998)$

16) 星 元 - 砂川和彦 (只羽化学)：特公開平 1-301664号 (1989)

17) The Pesticide Manual, Incorporating The Agrochemicals Handbook, Tenth Edition, Crop Protection Publications, p. 600, p. 669,1994

18）熊沢 智 - 伊藤篤史・最勝寺俊英 - 清水 進 - 江成宏之 美濃口正典·千田常明·佐竹慶吾：日本農薬学会第 16 回大 会講演要旨集, p. 148, 1991

19) A. J. Sampson, A. Cazenave, J-P. Laffranque, R. Glyn Jones, S. Kumazawa \& T. Chida: Proceedings 1992 Brighton Crop Protection Conference-Pests and Diseases, Vol. 1, p. 419,1992

20）佐竹慶吾.小林尚志：農薬時報 $<$ 臨時増刊 $>$, p. 13 (平成 6 年 12 月 10 日発行)

21) H. Tateishi, T. Saishoji, T. Suzuki \& T. Chida: Ann. Phytopathol. Soc. Jpn. 64, 443 (1998)

22) E. Thienpont, D. Navarro, N. Pollet \& P. Rime: Third International Conference on Plant Diseases, p. 217, Bordeaux, 1994

23) T. Eizuka, K. Saitoh, T. Chida, K. Satake \& I. Yamaguchi: J. Pesticide Sci. 19, 285 (1997) 


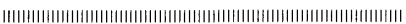

Society Awards 2000

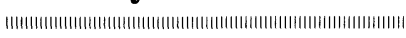

(on prominent achievement)

\section{Development of New Fungicides, Ipconazole and Metconazole}

\section{INTRODUCTION}

In the early 1980s our research target was to create environmentally safe and reliable agricultural chemicals with low dosage, low toxic and low resistance risk. Among several fungicidal chemical families, compounds containing an azole ring seemed to be promising and attractive for us. However, at our starting point, many so-called "azole type fungicides" had been already developed and commercialized, and some environmental problems and appearance of less-sensitive fungi had been reported for some fungicides of this family. We started the research for finding and developing a "highperformance" azole fungicide by organizing a project team consisting of organic chemists, biologists and computational chemists.

\section{PROCESS OF RATIONAL MOLECULAR DESIGN}

Our challenge to the rational design of potent and environmentally safe azole type fungicides with a novel skeletal structure was originated from the key idea; conformational control of two presumably important phenyl and azole (nitrogen containing heteroaromatic) rings for their favorable orientation with the corresponding interaction sites in the target enzyme, cytochrome P-450 $14 \mathrm{DM}$ (P-450 catalyzing lanosterol C-14 demethylation step) in the ergosterol biosynthetic pathway of fungi. For conformational constraint with moderate flexibility of the two aromatic rings, a cyclopentane ring was selected as a linker between them. ${ }^{1)}$ As a consequence, we were successful in discovering two novel fungicides, metconazole and ipconazole with a unique skeletal structure (1azolylmethyl-2-benzylcyclopentanol).

We first synthesized type I compounds (no alkyl groups at the cyclopentane ring) with various types of substituent in the phenyl moiety, and measured their in vitro and in vivo fungicidal activities against several fungi. We then applied the traditional Hansch-Fujita type of QSAR (Quantitative Structure-Activity Relationship) analyses to these compounds. ${ }^{2,3)}$ The QSAR correlation equations with the best statistical quality were expressed by the 1-octanol/water partition coefficient log $P$, its squared term $(\log P)^{2}$ and three steric parameters, which describe the three-dimensional (3D) shape of the phenyl moiety. These equations suggested that the introduction of a hydrophobic substituent of small bulk such as chlorine to the para position of the phenyl ring was most favorable to the fungicidal activity. At this stage we thus selected the para-chloro derivative as the best lead among 18 type I compounds.

The measured $\log P$ value of the lead (para-chloro type I derivative) is 3.11. From the above QSAR results, the optimum value of $\log P$ was estimated to be nearly 4 , being close to the average $\log P$ value of several typical commercial azole type fungicides. The difference between the predicted optimum $\log P$ value and that of the lead corresponds to the hydrophobic substituent constant value $\pi$ of $\mathrm{CH}_{3}$ or $\mathrm{C}_{2} \mathrm{H}_{5}$ group. The average molecular volume $M V$ of the other typical commercial azole type fungicides is also approximately $20 \AA^{3}$ (nearly corresponds to the volume of $\mathrm{CH}_{3}$ group) larger than the lead. Therefore, we planned to increase the hydrophobicity of the lead up to the predicted optimum values of $\log P$ and of $M V$. However, the QSAR results clearly indicated no more space for the introduction of hydrophobic groups into the phenyl moiety. In order to determine the best position for the introduction, we carried out the extensive 3D shape comparison between the lead and several other typical azole type fungicides, and simultaneously started to synthesize type II compounds (alkyl groups introduced at the cyclopentane ring). The least square superimposing procedure that takes account of conformational change of molecules (3D flexible superimposition) was developed for this purpose, and was then used here. The results indicated that the compound with gem-dimethyl group introduced at the 2 position of the cyclopentane ring (metconazole) was best fitted to each of the other azole type fungicides in terms of whole 3D molecular shape similarity scores. The results of the $3 \mathrm{D}$ comparison simultaneously indicated that the absolute configuration of its fungicidal active isomer and the active conformation (conformation when bound to the corresponding receptor). At this stage we experimentally confirmed that the optical $(-)$ isomer of metconazole exhibits 10 to 100 times higher fungicidal activity than its corresponding $(+)$ one.

After experimental confirmation of the dramatic activity enhancement of type II compounds, we again formulated QSAR correlation equations for the total combined set, type I and II total 32 compounds, by the 
introduction of an indicator variable which takes zero and unity for type I and II compounds, respectively. The physicochemical meaning of the indicator variable was later explained as a two-state variable related to the steric interaction energy by applying a novel 3D QSAR procedure, Voronoi Field Analysis, ${ }^{4}$ which we developed during the course of this work.

After confirming the dramatic increase of the fungicidal activity by the introduction of alkyl groups, we synthesized systematically several analogs with various alkyl substitutions at the cyclopentane ring and measured their biological activities. The potent fungicidal activity was observed in compounds with the alkyl group consisting of 2-3 carbon atoms. The apparent plant growth regulatory (PGR) activity (growth retardant effect which is common in many azole fungicides) was observed only in compounds with hydrogen-atom, mono-methyl or dimethyl group on the cyclopentane ring, and almost no PGR activity was seen in the compounds with ethyl, $n$-propyl, isopropyl, or other larger alkyls. ${ }^{5,6}$ The best position for the introduction of alkyl substituents for the fungicidal activity was confirmed to be the second position of the cyclopentane ring. We further studied the effect of the ring size of the cycloalkanol on the activity. As a result, we concluded that the cyclopentane ring structure was the best for potent fungicidal activity among cyclopentane, cyclohexane and cycloheptane rings. ${ }^{7}$ We finally selected metconazole and ipconazole as the candidates for further development and commercialization.

Based upon the results outlined above and the 3D structure of cytochrome P-450 cam (camphor binding P450, first 3D structure determined P-450, 1985), the binding mode of metconazole and ipconazole with the target cytochrome $\mathrm{P}-450_{14 \mathrm{DM}}$ was proposed at the molecular level.

The QSAR and 3D shape comparison approaches played essential roles in the process leading to the discovery of metconazole and ipconazole. Our two novel fungicides were thus emerged from our synergetic cooperation among us, organic chemists, biologists and computational chemists.

\section{BIOLOGICAL ACTIVITY OF METCONAZOLE AND IPCONAZOLE}

Both metconazole and ipconazole show a broad spectrum and high fungicidal activities against various fungi such as Ascomycetes, Bosideomycetes and Deuter- omycetes. Especially, their outstanding activities against Gibberella, Botrytis, Sclerotinia, Fusarium, Alternaria, Septoria, etc. bring beneficial characteristics to these fungicides for new azole type fungicides. There are no significant differences in the fungicidal activities between metconazole and ipconazole, however a characteristic and important difference is in their PGR activity. The PGR effect of ipconazole is much less than that of metconazole in any application methods. This is the main reason for their different application crops and methods.

Ipconazole possesses desirable property for a seedtreatment fungicide in terms of both fungicidal spectrum and plant safety. Ipconazole controls most important diseases for seed-treatment of rice such as "bakanae" disease, blast, Helminthosporium leaf spot, and seedling blight (Rhizopus and Trichoderma.) Due to its exceptional crop-safety, this chemical has a potential of seedtreatment on many other crops such as wheat, barley, corns, beans, and other broad leaf crops which are generally sensitive to azole compounds. Developmental work is on going.

Metconazole is very active on important cereal foliar diseases with a low dose, $90 \mathrm{~g}$ a.i./ha or less. This compound shows especially excellent control of Fusarium, Septoria and Rusts which are late application target diseases, therefore metconazole is recognized as one of the best late application fungicide for cereals. Recently metconazole was registered on oil-seed rape and have shown excellent yield improvement by both disease control and PGR effect for anti-lodging.

\section{REFERENCES}

1) S. Kumazawa, A. Ito, T. Saishoji \& H. Chuman: Japan Chemistry Program Exchange Newsletter 6 (4), 3 (1995)(in Japanese)

2) H. Chuman, A. Ito, T. Saishoji \& S. Kumazawa: “Classical and 3D-QSAR in Agrochemistry," ed. by C. Hansch \& T. Fujita, ACS Symposium Series 606, American Chemical Society, Washington, D.C., p. 171, 1995

3) T. Fujita: Quant. Struct.-Act. Relat. 16, 107 (1997)

4) H. Chuman, M. Karasawa \& T. Fujita: Quant. Struct.-Act. Relat. 17, 313 (1998)

5) A. Ito, T. Saishoji \& S. Kumazawa: J. Pesticide Sci. 22, 119 (1997)

6) T. Saishoji, A. Ito, S. Kumazawa \& H. Chuman: J. Pesticide Sci. 23, 129 (1998)

7) A. Ito, T. Saishoji, S. Kumazawa \& H. Chuman: J. Pesticide Sci. 24, 262 (1999) 